\title{
Genetic Mapping of a Body Weight Trait in Chicken
}

\author{
Ken TATSUDA, Kuninori FUJINAKA and Toshinobu YAMASAKI \\ Hyogo Prefectural Agricultural Institute, Kasai-shi 679-0189, Japan
}

(Received September 24, 1999 ; Accepted December 15, 1999)

\begin{abstract}
The indigenous chicken line, Satsumadori (SD), is characterized by slow growth and widely varied body weight. We carried out linkage analysis on chicken growth traits using a resource population between a SD male and a White Leghorn female, comprising $232 \mathrm{~F}_{2}$. We chose 72 microsatellite loci among 244 loci publicly available of 19 autosomal linkage groups, in terms of their utilities and locations. A quantitative trait loci (QTL) affecting body weight at 13 weeks was mapped at $122.8 \mathrm{cM}$ on chromosome 1 (LOD score $=5.16$ ). The closest loci were ADL19 and ADL192. The difference in body weight of $F_{2}$ were associated with allele types of ADL19 and ADL192 (P<0.01). In $52 \mathrm{SD}$ males, we found three alleles of ADL19, each of which was assumed to be associated with the body weight at 13 weeks ( $P=0.062)$. Therefore, ADL19 will be applicable to marker-assisted selection for body weight in SD-crossed commercial populations.
\end{abstract}

Animal Science Journal 71 (2) : 130-136, 2000

Key words : Chicken, QTL, Growth, Microsatellite

Recently, many studies have been carried out on quantitative trait loci (QTL) analysis of livestock related to economic traits or diseases. A lot of DNA markers like microsatellites have been developed and mapping on the linkage map is being extensively performed ${ }^{2-14,17,19-22,25} 28$. In addition, experimental populations are being developed and linkage analysis is being carried out on these markers for various traits or diseases ${ }^{1,16,18,29,30)}$. Georges et al. ${ }^{16)}$ have identified five chromosomes giving very strong evidence for the presence of a QTL controlling milk production : chromosomes 1, 6, 9, 10 and 20. Andersson et al. ") found evidence for QTLs on chromosome 4 with large effects on growth, length of the small intestine and fat deposition in pigs. In chickens, Groenen et al. ${ }^{18)}$ found that the QTL for body weight at 48 days of age in broilers is on chromosome 1, van Kaam et al. ${ }^{30)}$ found that the QTL for feed intake in broilers is on chromosome 1, and Vallejo et al. ${ }^{29)}$ reported two significant QTLs and two suggestive QTLs for Marek's disease on four chromosomal subregions: chromosomes 2, 4, 7 and 8 .
On the other hand, the special chicken HyogoAjidori of Hyogo Prefecture, is a three-way cross, produced by crossing an inferior White Plymouth Rock with a Hyogo, which is a two-way cross between a Satsumadori (SD) male and a Nagoya female. SD is a native breeds in Japan and no improvement has been done on its growth. Among these three breeds, the growth of SD is the worst, and body weights vary widely among individuals. As a result, a similar tendency is also seen in the growth of Hyogo and Hyogo-Ajidori. To improve the productivity of Hyogo-Ajidori, we carried out QTL analysis on the growth of SD males.

\section{Materials and Methods}

\section{Experimental population}

Two male and ten female $F_{1} s$ were produced from a SD male and a White Leghorn (WL) female, and 129 male and 103 female of $F_{2} \mathrm{~S}$ were obtained by crossing $F_{1}$ individuals. These 246 animals were used as the experimental population. The body weight just before the experiment (at about 1 year of age) of the

Corresponding : Ken TATSUDA (fax : +81 (0) 790-47-0549, e-mail : niwatori@ sannet.ne.jp)

Anim. Sci. J. 71 (2) : 130-136, 2000 


\section{QTL Affecting Growth in Chicken}

$\mathrm{SD}$ male was $4.3 \mathrm{~kg}$. The $\mathrm{F}_{2} \mathrm{~s}$ were hatched in three periods, reared in young-chick cages untill 4 weeks of age, and in chick-rearing cages untill 13 weeks of age. Thirteen weeks is the target shipment age for HyogoAjidori. Feeds on the market for stud young chicks (CP $19.0 \%$ and ME 2,900 kcal/kg) and for stud middle-large chicks (CP 14.5\% and ME $2,750 \mathrm{kcal} /$ $\mathrm{kg}$ ) were fed respectively untill 4 weeks of age and thereafter. During the experimemtal period, feed and water were supplied at ad libtim consumption and no illumination. The body weights of the $232 \mathrm{~F}_{2}$ individuals at 13 weeks of age were measured.

\section{$52 S D$ males}

Apart from the above experimental population, 52 SD males were reared in the same way and their body weights were measured at 13 weeks of age. There was no parent-offspring relationship between the experimental SD male and these 52 SD males. They were from several parent groups.

\section{DNA samples}

Blood samples were collected from the 246 individuals of the experimental population. $40 \mu \mathrm{l}$ of blood was diluted to $200 \mu l$ with $160 \mu l$ of PBS (-), and DNA was extracted with a QIAamp Blood Kit (QIAGEN). The average DNA concentration was $167 \mu \mathrm{g} / \mathrm{ml}$, and all were adjusted to $20 \mu \mathrm{g} / \mathrm{m} l$.

\section{Microsatellite markers (markers)}

We used the 244 primers : Comprehensive Mapping Kit\#1, 120 primer pairs ${ }^{4,6,7,10,11,2022,25)}$ and Comprehensive Mapping Kit \#2, 124 primer pairs ${ }^{4,6,7,10-12,20-22,25)}$ which are open on the homepage of the Chicken Genome Project (http://poultly. mph.msu.edu/).

\section{$P C R$}

PCR amplifications were carried out in $16.5 \mu \mathrm{l}$ reaction mixtures containing $20 \mathrm{ng}$ DNA, $50 \mathrm{mM} \mathrm{KCl}, 10$ $\mathrm{mM}$ Tris- $\mathrm{HCl}(\mathrm{pH} 8.3), 1.5 \mathrm{mM} \mathrm{MgCl}, 200 \mu \mathrm{M}$ each of the 4 dNTPs, 0.5 units AmpliTaq Gold DNA polymerase (Perkin-Elmer) and 5 pmol of each of the primer pairs. The reaction was performed by predenaturing at $95^{\circ} \mathrm{C}$ for $9 \mathrm{~min}$, then 43 cycles of denaturation at $94^{\circ} \mathrm{C}$ for $30 \mathrm{sec}$, annealing at the temperature set for each primer $\left(43 \sim 60^{\circ} \mathrm{C}\right)$ for $1 \mathrm{~min}$, and finally an extension at $60^{\circ} \mathrm{C}$ for $10 \mathrm{~min}$.

\section{Electrophoresis and DNA Genotyping}

Primers were divided into several groups by the length and fluorescence of the PCR products. Electrophoresis was carried out with $5.7 \%$ polyacrylamide gel $(36 \mathrm{~cm})$ on a sequencer $(373 \mathrm{~S}$; ABI, PerkinElmer) for $11 \mathrm{~h}$ and the results were analyzed with software from Genescan and Genotyper (ABI, Perkin-Elmer).

\section{QTL analysis}

QTL analysis was performed using MAPMAKER/ QTL ${ }^{23 !}$. The positions of the markers on each linkage group and the distances between markers were referred to the map of East Lancing ${ }^{15)}$ on the homepage of the Roslin Institute (http ://www.ri.bbsrc. ac.uk/cgi-bin $/$ mapviewer? species $=$ chicken $)$.

\section{Results}

\section{Body weights of $F_{2}$ individuals}

Body weights and standard deviations are shown in Table 1 for $F_{2}$ individuals at 13 weeks of age, hatched in three periods. No significant difference was seen in each group for both males and females. Correction of the body weight differences between males and females was done by subtracting the average body weight of the females from that of the males, and adding the value obtained to the body weight of the females.

\section{Information on markers}

There were 38 markers with unclear fluorescence and PCR temperature among the 244 markers used. There were 14,9 and 44 markers which failed to identify the genotypes in SD, in WL and in both SD and WL respectively, due to the failure of DNA amplification in PCR. There were also 33 markers with which the genotypes of SD and WL were identical. These 138 markers in total, therefore, could not be used in the genotype identification. The heterogeneity of SD was $37.2 \%$, and $39.9 \%$ in WL. Among the 206 markers examined, there were 149 ADL (Avian Disease and Oncology Laboratory, Michigan State University, East Lancing, MI) markers and 57 MCW (Microsatellite Chicken Wageningen, The Netherlands) markers. In comparison, $35.6 \%$ of the ADL markers, and $8.8 \%$ of the MCW markers could not identify the genotypes due to the failure of DNA amplification in PCR for SD. Similarly, $32.2 \%$ of 
TATSUDA, FUJINAKA and YAMASAKI

Table 1. Body weight of $F_{2}$ individuals at 13 weeks of age

\begin{tabular}{|c|c|c|c|c|c|}
\hline Sex & & Hatch 1 & Hatch 2 & Hatch 3 & Total \\
\hline Male & $\begin{array}{c}\text { Number of birds } \\
\text { Mean } \pm \text { S.D. } \\
\text { Maximum } \\
\text { Minimum }\end{array}$ & $\begin{array}{c}53 \\
1,682 \pm 232 \\
2,100 \\
820\end{array}$ & $\begin{array}{c}48 \\
1,742 \pm 165 \\
2,080 \\
1,350\end{array}$ & $\begin{array}{c}28 \\
1,634 \pm 155 \\
1,930 \\
1,310\end{array}$ & $\begin{array}{c}129 \\
1,694 \pm 197 \\
2,100 \\
820\end{array}$ \\
\hline Female & $\begin{array}{l}\text { Number of birds } \\
\text { Mean } \pm \text { S.D. } \\
\text { Maximum } \\
\text { Minimum }\end{array}$ & $\begin{array}{c}13 \\
1,368 \pm 212 \\
1.880 \\
700\end{array}$ & $\begin{array}{c}23 \\
1,308 \pm 151 \\
1,600 \\
990\end{array}$ & $\begin{array}{c}37 \\
1,375 \pm 135 \\
1,620 \\
1,070\end{array}$ & $\begin{array}{c}103 \\
1,357 \pm 175 \\
1,880 \\
700\end{array}$ \\
\hline $\begin{array}{l}\text { Male and female } \\
\text { (corrected) }\end{array}$ & $\begin{array}{l}\text { Number of birds } \\
\text { Mean } \pm S . D \text {. } \\
\text { Maximum } \\
\text { Minimum }\end{array}$ & $\begin{array}{c}96 \\
1.692 \pm 222 \\
2,217 \\
820\end{array}$ & $\begin{array}{c}\quad 71 \\
1,710 \pm 166 \\
2,080 \\
1,327\end{array}$ & $\begin{array}{c}65 \\
1,678 \pm 148 \\
1,957 \\
1,310\end{array}$ & $\begin{array}{c}232 \\
1,694 \pm 186 \\
2,217 \\
820\end{array}$ \\
\hline
\end{tabular}

the ADL markers and $8.8 \%$ of the MCW markers could not identify the genotype in WL. The heterogeneity in ADL markers with which genotypes were identified, was $32.3 \%$ in SD and $38.6 \%$ in WL. Similarly in MCW markers, it was $46.2 \%$ in SD and 42.3\% in WL. Among the 106 markers which had been judged to be usable, 21 were found to be inapplicable due to the failure of PCR in $\mathrm{F}_{2}$. In addition, where there was only one marker in a linkage group, the marker was not used, and where there were several markers on the same position, only one was used in the analysis. Therefore, 72 markers of 19 autosomal linkage groups were finally chosen for the QTL analysis (Table 2).

\section{QTL analysis}

One QTL was found in the linkage analysis, between genotype and body weight at 13 weeks of age in the $F_{2}$ (Fig. 1). This QTL was on a position between ADL19 and ADL192, and $6.0 \mathrm{cM}$ from ADL19 on chromosome 1 ( $122.8 \mathrm{cM}$ of chromosome 1 ), and the distance from ADL19 to ADL192 is $23.5 \mathrm{cM}$. The LOD score was 5.16, showing the highest value. Among the markers used, ADL 19 and ADL192 were the nearest loci to this part. The variance explained of this QTL was $18.3 \%$.

Effects on $F_{2}$ body weight by the ADL19 and ADL192 alleles, and in 52 SD males by the ADL 19 allele

Table 3 shows the relationship between the ADL19 and ADL192 alleles nearest to the QTL, and body weight at 13 weeks of age in the $F_{2}$, and the ADL19 allele and body weight at 13 weeks of age in $52 \mathrm{SD}$ males. The ADL 19 allele type of SD was shown by AA ( $93 \mathrm{bp}$ ), and in WL by BB (95bp). The ADL 192 allele type of SD was shown by AA (139 bp) and in WL by AB ( 137 bp, 139 bp). In either case, there were significant differences in body weight depending on the allele $(\mathrm{P}<0.01)$, and the $F_{2}$ body weight of $B$ type was heavier than that of A type. In $52 \mathrm{SD}$ males, there were three alleles in ADL 19 and all were homozygous (AA : $93 \mathrm{bp}, \mathrm{CC}: 103 \mathrm{bp}, \mathrm{DD}: 109 \mathrm{bp}$ ). The majority was occupied by one allele and a difference in body weight was seen in different alleles $(\mathrm{P}=$ 0.062). The alleles of ADL192 were all identical.

\section{Discussion}

In QTL analysis, it is important to repress as much as possible the impact of environment on the target trait, and the number of individuals in a family line used in analysis can be several hundred. Because of this, when $F_{2}$ individuals are produced, the individuals have to be reared dividing into several periods, as it is difficult to control all the individuals at the same time. In this case, environmental factors like rearing location and season will have some impact on the target trait, and the larger the rearing area and the longer the generation alteration time, as in large livestock, the larger the impact will be. From this respect, chickens are favorable for use in linkage analysis since it is possible to make a number of family lines in a short time, and to control the individuals in the same conditions. Crooijmans et al. ${ }^{12)}$ described that chickens are an excellent model system for the application of 
QTL Affecting Growth in Chicken

Table 2. Linkage groups and markers used in QTL analysis

\begin{tabular}{cccc}
\hline \hline $\begin{array}{c}\text { Linkage } \\
\text { group }\end{array}$ & $\begin{array}{c}\text { Number of } \\
\text { markers }\end{array}$ & $\begin{array}{c}\text { Genome } \\
\text { coverage (cM) }\end{array}$ & $\begin{array}{c}\text { Average } \\
\text { interval (cM) }\end{array}$ \\
Chromosome 1 & 13 & 394.80 & 30.37 \\
Chromosome 2 & 9 & 460.04 & 51.12 \\
Chromosome 3 & 5 & 287.13 & 57.43 \\
Chromosome 4 & 5 & 111.62 & 22.32 \\
Chromosome 5 & 6 & 167.24 & 27.87 \\
Chromosome 6 & 4 & 44.99 & 11.25 \\
Chromosome 7 & 2 & 112.89 & 56.45 \\
Chromosome 8 & 4 & 50.13 & 12.53 \\
E 27 & 2 & 5.80 & 2.90 \\
E 29 & 3 & 29.65 & 9.88 \\
E 30 & 2 & 32.60 & 16.30 \\
E 31 & 2 & 79.96 & 39.98 \\
E 35 & 2 & 23.58 & 11.79 \\
E 36 & 2 & 118.37 & 59.19 \\
E 41 & 2 & 13.18 & 6.59 \\
E 46 & 2 & 22.77 & 11.39 \\
E 47 & 2 & 13.59 & 6.80 \\
E 48 & 2 & 14.52 & 7.26 \\
E 53 & 3 & 71.38 & 23.79 \\
\hline Total & 72 & $2,054.24$ & 28.53 \\
\hline
\end{tabular}

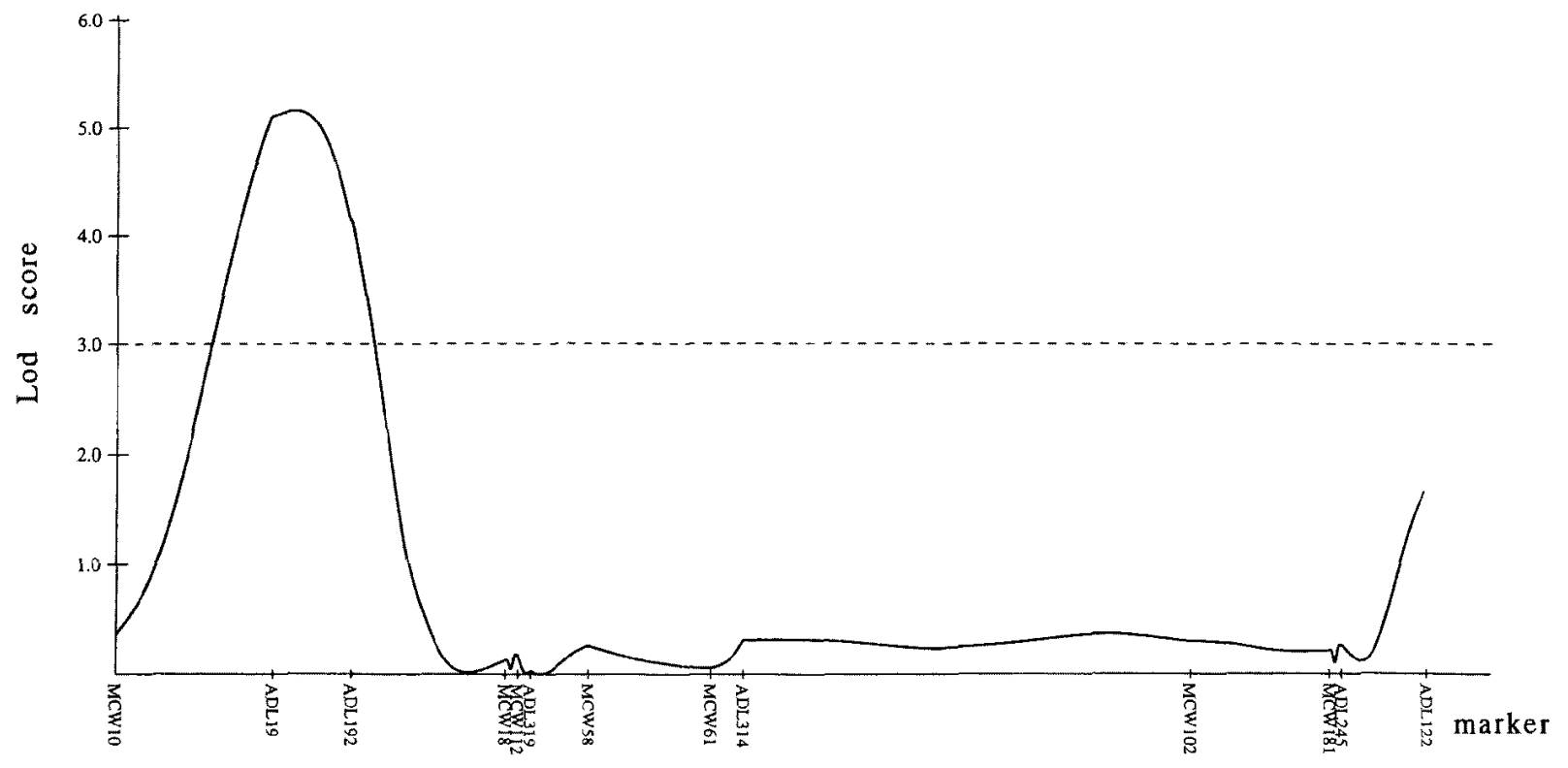

Fig. 1. Lod scores on chromosome 1. 
Table 3. Relationship between the allele of ADL19 and ADL192 and body weight at 13 weeks of age in $F_{2}$, and the allele of ADL19 and body weight at 13 weeks of age in $52 \mathrm{SD}$ males

\begin{tabular}{|c|c|c|c|c|}
\hline Bird & Marker & $\begin{array}{l}\text { Allele } \\
\text { type }\end{array}$ & $\begin{array}{l}\text { Number } \\
\text { of birds }\end{array}$ & $\begin{array}{c}\text { Body } \\
\text { weight }(g)\end{array}$ \\
\hline \multirow[t]{6}{*}{$\mathrm{F}_{2}$} & \multirow[t]{3}{*}{ ADL19 } & $\mathrm{AA}$ & 24 & $1,578^{c}$ \\
\hline & & $\mathrm{AB}$ & 70 & $1,673^{b}$ \\
\hline & & $\mathrm{BB}$ & 52 & $1.759^{a}$ \\
\hline & \multirow[t]{3}{*}{ ADL 192} & AA & 109 & $1,652^{b}$ \\
\hline & & $\mathrm{AB}$ & 54 & $1,736^{\mathrm{a}}$ \\
\hline & & $\mathrm{BB}$ & 10 & $1,792^{a}$ \\
\hline \multirow{3}{*}{$\begin{array}{l}52 \mathrm{SD} \\
\text { males }\end{array}$} & \multirow[t]{3}{*}{ ADL19 } & $\mathrm{AA}$ & 39 & $1,802^{e}$ \\
\hline & & $\mathrm{CC}$ & 9 & $1,658^{f}$ \\
\hline & & DD & 4 & $1,915^{\mathrm{d}}$ \\
\hline
\end{tabular}

a, b.c Values in the same bird and same marker with different superscripts are significantly different, $\mathbf{P}<$ 0.01 .

d.e.f Values with different superscripts are suggestive different, $\mathrm{P}<0.10$.

genetic mapping technology because of its short generation interval and the possibility to generate large full-sib families. Vallejo et al. ${ }^{29)}$ stated a similar position. Also in this study, no significant difference in average body weight was found in three hatch groups, and the data was effective for QTL analysis.

On markers, ADL markers are those developed from the experimental population produced by the back-crossing of Red Jungle Fowl and WL, the socalled East Lancing reference population ${ }^{15\rangle}$. Besides, MCW markers have been developed by back-crossing of WLs of different lineage which are called the Compton reference population ${ }^{3}$. The difference in utility between SD and WL was small, but difference between the kinds of markers was as large as 4-fold. This indicates that in an experimental population, different kinds of markers may have different problems in PCR, even under the same conditions. The heterogeneity of $\mathrm{MCW}$ markers was higher than that of ADL markers. A high heterogeneity indicates easy identification of a heredity pattern of markers from parents to the next generation. Based on these results, MCW markers are considered to be more useful than ADL markers in this experimental population. Besides, new markers have been reported by Crooijmans et al. ${ }^{13)}$, so $\mathrm{MCW}$ markers are thought to be effective in linkage analysis hereafter.

From the results of the QTL analysis, the LOD score showed a high value of 5.16. The LOD score threshold was derived by Lander and Botstein ${ }^{24}$, and a LOD score above 3 indicates a significant linkage. According to this, the LOD score of 5.16 in this study is thought to be a relatively strong linkage. Groenen et al. ${ }^{18)}$ suggested that the QTL for body weight at 48 days of age in broilers was on $220 \mathrm{cM}$ of chromosome 1 , and van Kaam et $\mathrm{al}^{31}{ }^{31}$, though using suggestive linkage, suggested that the QTL for body weight at 48 days of age in broilers was on $240 \mathrm{cM}$ and the QTL for growth was on $235 \mathrm{cM}$. Although we cannot compare this data directly with the results of our study due to the differences in chicken breeds, days of age, and the experimental population which was referred, it is certain that the QTL affecting growth of chickens is on chromosome 1. In this study, we used the existing marker-kit, but contrary to our expectation, it turned out to be that a number of markers could not be used in the QTL analysis. As a result, we failed to cover the whole genome and there are still some long distances between the markers. Though it is possible that the QTL is in a position outside the parts covered in this study, from the results of other studies to date, any QTL concerning growth is found in only one place on the genome $\mathrm{e}^{18,30,31)}$. van Kaam et al. ${ }^{30)}$ described the possibility that a single QTL affects growth. In addition, the distance of markers within which a QTL was found in this study is $23.5 \mathrm{~cm}$, which is relatively short. Though we did not use very many markers in this study, we were fortunate to have found the position of a QTL affecting growth. In fact, when we compared the allele of the marker nearest to the QTL (ADL19 and ADL192), and the body weights of the $F_{2}$ at 13 weeks of age, we found a significant difference in body weight by allele. Furthermore, we compared the allele of ADL19 and the body weights of 52 SD males at 13 weeks of age, then in spite of some lean to an allele, the difference in body weight by allele was seen ( $P=0.062$ ), and specifically the body weight of allele DD was $15 \%$ more than that 


\section{QTL Affccting Growth in Chicken}

of CC. These results indicate the existence of a QTL for growth on this part, and the marker-assisted selection for body weight in SD-crossed commercial populations is possible using marker ADL19.

\section{Acknowlegements}

We are grateful to Dr. Hans Cheng, Department of Agriculture, Agricultural Research Service, Avian Disease and Oncology Laboratory, United States for his provision of microsatellite markers, to Dr. Yoshikazu Sugimoto, Institute of Animal Genetics, Shirakawa, Japan for his critical comment and reading of the manuscript, and to Dr. Kazuo Hara, Institute of Animal Genetics, Shirakawa, Japan for his work in QTL analysis.

\section{References}

1) Andersson L, Haley CS, Ellegren $\mathbf{H}$, Knott SA, Johansson M, Andersson K, Andersson-Eklund L, Edfors-Lilja I, Fredholm M, Hansson I, Hakansson $\mathrm{J}$, Lundstrom $\mathrm{K}$. Genetic mapping of quantitative trait loci for growth and fatness in pigs. Science, 263: 1771-1774. 1994.

2) Bishop MD, Kappes SM, Keele JW, Stone RT, Sunden SLF, Hawkins GA, Toldo SS, Fries R, Grosz MD, Yoo J, Beattie CW. A genetic linkage map for the cattle. Genetics, $136: 619-639.1994$.

3) Bumstead $\mathbf{N}$, Palyga J. A preliminary linkage map of the chicken genomc. Genomics, $13: 690-697.1992$

4) Burt DW. Mapping the chicken ACTA2 locus using heteroduplex polymorphisms. Animal Genetics, 25 : 199. 1994.

5) Burt DW, Bumstead N, Bitgood JJ, Ponce De Leon FA, Crittenden LB. Chicken genome mapping a new era in avian genetics. Tig May, 11 : 190-194. 1995.

6) Cheng HH, Crittenden LB. Microsatellite markers for genetic mapping in the chicken. Poultry Science, 73 : $539-546.1994$.

7) Cheng HH, Levin I, Vallejo RL, Khatib H, Dodgson JB, Crittenden LB, Hillel J. Development of a genetic map of the chicken with markers of high utility. Poultry Science, 74 : 1855-1874. 1995.

8) Cheng HH. Mapping the chicken genome. Poultry Science, 76 : 1101-1107. 1997.

9) Crooijmans RPMA, van Kampen AJA, van der Poel JJ, Groenen MAM. Highly polymorphic microsatellite markers in poultly. Animal Genetics, $24: 441$ $-443.1993$.
10) Crooijmans RPMA, van Kampen AJA, van der Poel JJ, Groenen MAM. New microsatellite markers on the linkage map of the chicken genome. Journal of Heredity, 85: 410 413. 1994.

11) Crooijmans RPMA, van der Poel JJ, Groenen MAM. Functional genes mapped on the chicken genome. Animal Genetics, 26 : 73-78. 1995.

12) Crooijmans RPMA, Van Oers PAM, Strijk JA, van der Poel JJ, Groenen MAM. Preliminary linkage map of the chicken (Gallus domesticus) genome based on microsatellite markers : 77 new markers mapped. Poultry Science, 75 : 746-754. 1996.

13) Crooijmans RPMA, Dijkhof RJM, van der Poel JJ, Groenen MAM. New microsatellite markers in chicken optimized for automated fluorescent genotyping. Animal Genetics, 28 : 427-437. 1997.

14) Crawford AM, Dodds KG, Ede AJ, Pierson CA, Montgomery GW, Garmonsway HG, Beattie AE, Davies K, Maddox JF, Kappes SW, Stone RT, Nguyen TC, Penty JM, Lord EA, Broom JE Buitkamp J, Schwaiger W, Epplen JT, Matthew P, Matthews ME, Hulme DJ, Beh KJ, McGraw RA, Beattie C. An autosomal genetic linkage map of the sheep genome. Genetics, 140:703-724. 1995.

15) Crittenden LB, Provencher L, Santangelo L, Levin I, Abplanalp H, Briles RW, Briles WE, Dodgson JB. Caracterization of a Red Jungle Fowl by White Leghorn backcross reference population for molecular mapping of the chichen genome. Poultry Science, $72: 334-348.1993$.

16) Georges $M$, Nielsen D, Mackinnon M, Mishra A, Okimoto R, Pasquino AT, Sargeant LS, Sorensen A, Steele MR, Zhao X, Womack JE, Hoeschele I Mapping quantitative trait loci controlling milk production in dairy cattle by exploiting progeny testing. Genetics, 139 : 907-920. 1995.

17) Gibbs M, Dawson DA, McCamley C, Wardle AF, Armour JAL, Burke T. Chicken microsatellite markers isolated from libraries enriched for simple tandem repeats. Animal Genetics, 28 : 401-417. 1997.

18) Groenen MAM, Crooijmans RPMA, Veenendaal $T$, Van Kaam JBCH, Vereijken ALJ, van Arendonk JAM, van der Poel JJ. QTL mapping in chicken using a three generation full sib family structure of an extreme broiler $\times$ broiler cross. Animal Biotechnol ogy, $8: 41-46,1997$.

19) Groenen MAM, Crooijmans RPMA, Veenendaal A, Cheng HH, Siwek M, van der Poel JJ. A comprehensive microsatellite linkage map of the chicken genome. Genomics, 49 : 265-274. 1998. 


\section{TATSUDA, FUJINAKA and YAMASAKI}

20) Khatib H, Genislav E, Crittenden LB, Bumstead N, Soller M. Sequence-tagged microsatellite sites as markers in chicken reference and resource populations. Animal Genetics, 24 : 355-362. 1993.

21) Khatib H, Soller M. Mononucleotide repeat polymorphism at the GGY locus in chicken. Animal Genetics, $24: 397.1993$.

22) Khatib H, Genislav E, Soller M. Chicken microsatellites at the HUJERELA and HUJ106 loci. Animal Genetics, 25 : 55. 1994.

23) Lander ES, Green P, Abrahamson J, Barlow A, Daly MJ, Lincoln SE, Newburg L. MAPMAKER : an interactive computer package for constructing primary genetic linkage maps of experimental and natural populations. Genomics, 1 : 174-181. 1987.

24) Lander ES, Botstein D. Mapping mendelian factors underlying quantitative traits using RFLP linkage maps. Genetics, $121:$ 185-199. 1989.

25) Levin I, Santangello L, Cheng HH, Crittenden LB, Dodgson JB. An autosomal genetic linkage map of the chicken. Journal of Heredity, 85 : 79-85. 1994.

26) Levin I, Cheng HH, Baxter-Jones C, Hillel J. Turkey microsatellite DNA loci amplified by chicken-specific primers. Animal Genetics, 26 : 107-110. 1995.

27) Marklund L, Johansson Moller M, H $\Phi$ yheim B,
Davis W, Fredholm M, Juneja RK, Mariani P, Coppieters W, Ellegren H, Andersson L. A comprehensive linkage map of the pig based on a WildPigLargeWhite intercross. Animal Genetics, $27: 255^{-}$ 269. 1996.

28) Smith EJ, Lyons LA, Cheng HH, Suchyta SP. Comparative mapping of the chicken genome using the East Lansing reference population. Poultry Science, 76: 743-747. 1997.

29) Vallejo RL, Bacon LD, Liu HC, Witter RL, Groenen MAM, Hillel J, Cheng HH. Genetic mapping of quantitative trait loci affecting susceptibility to Marek's discase virus induced tumors in $F_{2}$ intercross chickens. Genetics, 148: 349-360. 1998.

30) van Kaam JBCHM, van Arendonk JAM, Groenen MAM, Bovenhuis $\mathrm{H}$, Vereijken ALJ, Crooijmans RPMA, van der Poel JJ, Veenendaal A. Whole genome scan for quantitative trait loci affecting body weight in chickens using a three generation design. Livestock Production Science, 54 : 133-150. 1998.

31) van Kaam JBCHM, Groenen MAM, Bovenhuis $\mathbf{H}$, Veenendaal A, Vereijken ALJ, van Arendonk JAM. Whole genome scan in chickens for quantitative trait loci affecting growth and feed efficiency. Poultry Science, $78: 15-23.1999$. 